\title{
ORTHODOX RELIGIOSITY IN MODERN BELARUS: AFTER TRADITION'S BREAK (PRELIMINARY DATA)
}

\author{
Svetlana Karassyova
}

DOI: 10.17846/CL.2016.9.1.215-224

\begin{abstract}
KARASSYOVA, Svetlana. Orthodox Religiosity in Modern Belarus: After Tradition's Break (Preliminary Data). Religiosity in Belarus, one of the post-Soviet republics, is determined today by a strong pre-revolutionary (1917) influence of the Orthodox tradition (successor of the Byzantine Christianity); the remaining of directive atheism of the Soviet period; the rapid post-Soviet revival of religiosity; the domination of forms, ethnocultural religiosity since the mid-2000s. The following stabilisation of growth of confessional structure of religiosity in the country contributed to the growth of consciousness in religious stance of the population, which is proved by the represented data.
\end{abstract}

Key words: religiosity, revival of religiosity, post-Soviet religiosity, post-Soviet Orthodoxy

\begin{abstract}
Abstrakt: KARASJEVA, Svetlana. Religiozita v súčasnom Bielorusku po tom, čo bola pretrhnutá náboženská tradícia. Religiozita v Bielorusku, bývalej sovietskej republike je dnes určená viacerými faktormi: predrevolučným vplyvom pravoslávnej tradície (nasledovatelia byzantského krestanstva); pozostatkami nariadovaného ateizmu sovietskeho obdobia; rapídnym post-sovietskym oživením religiozity, dominanciou foriem, etno-kultúrnou religiozitou od polovice prvej dekády 21. storočia. Následná stabilizácia rastu náboženskej štruktúry religiozity v krajine dopomohla rastu uvedomenia si náboženského postoja populácie. Svedčia o tom fakty prezentované v príspevku.
\end{abstract}

Klúčové slová: religiozita, oživenie religiozity, post-sovietska religiozita, post-sovietska ortodoxia

One of the ideological components in the pre-revolutionary (1917) Russia was the tradition of hesychastic prayer $^{1}$, going back to Byzantine tradition. The ideal of Russian hesychastic practice was a personal transfiguration and further transfigured service to God and the people, and the world.

This idea later became the basis for one of the programmes of Russian religious philosophy. ${ }^{2}$ At the beginning of the XX century, this programme was made topical by its creators (N. Berdyaev, Fr. Sergius Bulgakov, N. Trubetskoy et al.) as one of the alternatives for "saving" (as in, revival and enlightenment of) Russia.

Both religious and religious-and-philosophical traditions were interrupted in Russia, for the first time in 1917 (with socialist - and atheistic - revolution) and then in 1922 (with the famous "philosophers' ships", banishment of the non-Marxist philosophers from the country).

Откровенные рассказы странника духовному своему отиу. Москва 2009.

2 СОЛОВЬЕВ, Владимир Сергеевич. Чтения о богочеловечестве. Москва 2014; БЕРДЯЕВ, Николай Александрович. Русская идея. Санкт-Петербу́рг 2008; ФЛОРЕНСКИЙ, Павел. Александрович. Столпа и утверждения истины. Москва 1990. 
The above-mentioned religious programme, salvation through ascetic transfigured serving of God and the world, was not mainstream in the interrupted Orthodox tradition. ${ }^{3}$

The basic model of the pre-revolutionary Orthodoxy was the authoritative-communal one. Individual religiosity, hesychastic in particular, gave just individual, though striking, examples throughout centuries: Cyprian, the Metropolitan of Kiev (XIV); Sergius of Radonezh (XV); Nil Sorsky (XV); Paisius Velichkovsky (XVII).

After the fall of USSR in 1991, its former republics witnessed a rapid revival of religiosity. Basic prerevolutionary religious traditions (especially Orthodoxy) gathered their followers rapidly and massively.

Since Orthodoxy was a dominant religious tradition in Belarus, just as in Russia in the pre-revolutionary times, a logical question arises: which model of religiosity was restored in Belarus, same as in Russia, after the Soviet intervention?

Almost all post-Soviet surveys (in both countries) demonstrated a formal nature of the restored religiosity: ${ }^{4}$ people declared themselves adherent to a certain religion, including Orthodoxy, due to ethic-cultural memory - a Russian is Orthodox, a Tatar is Muslim, a Polish is Catholic, a Jew is Judaist, etc. What exactly stands for "Orthodox" or "Muslim" or other religions did not matter for a long time; it was only important to bring back the original identity.

Sociologists have called this phenomenon an ethnic-cultural or declared religiosity, i.e. lacking proper (religious) meaning. ${ }^{5}$

But formal religiosity has gradually recovered its authenticity; first of all, on individual or micro-level, in small numbers. Speaking of the social, or macro-level, the processes of institutionalisation (in Russia) and communal consolidation (in Belarus) took place. In Russia, Orthodox revival moved into the sphere of inner politics; in Belarus, into communal collectivism.

In both cases, macro-processes started dominating over micro-processes, which meant, and still means, a weak individual component of religion, a level on which the very work of reaching salvation though the transfigured serving of God and the world takes place.

Studying religious population of Belarus in $2012-2014^{6}$ shows the same peculiarity - the respondents understand religion as an abstract value and/or as a comfortable communal environment. Religion is, for the Belarusian, still a symbol of identity, not a life programme. Nonetheless, a question arises: is there at least some background or hope for reviving the pre-revolutionary tradition of deep and active individual (in particular, hesychastic) religiosity, which was not strong, but important in Russian Orthodoxy?

The diagrams ${ }^{7}$ below describe the followers of 19 religions, denominations and movements in Belarus; however, the general tone is largely set by the representatives of Orthodoxy $(47.3 \%$ of the respondents).

3 СКОБЦОВА, Мария (монахиня). Типы религиозной жизни. Москва 2002. Церковный вестник (Church Journal) published by the Holy Synod of the Russian Orthodox Church (1901-1916). Weekly edition with additions. Saint-Petersburg.

4 КААРИАЙНЕН, Киммо - ФУРМАН, Дмитрий Ефимович (eds.). Старые Церкви, новые верующие. Религия в массовом сознании постсоветской России. Москва; Санкт-Петербу́рг 2000.

5 НОВИКОВА, Лидия Георгиевна. Религиозность в Беларуси на рубеже веков: тенденции и особенности проявления (соииологический аспект). Минск 2001.

6 КАРАСЕВА, Светлана Геннадьевна - ШКУРОВА, Елена Валерьевна. Многомерный кроссконфессиональный подход к исследованию религиозности в Беларуси: актуальность и концептуализация. In: Социология, 2012, с̌. 3, p. 123-133.

7 All the diagrams contain data of the republican research reflecting some characteristics of identification of the religious part of the post-Soviet (i.e. post-atheistic) Belarusian population, which has witnessed a "religious boom". The main question of the research was: what do people mean by identifying themselves as religious, as Orthodox in particular, what are they ready to do for their faith. For the methodology of the research, see: КАРАСЕВА - ШКУРОВА, Многомерный кроссконфессиональный подход, p. 123-133. 
What is the role of faith (religion) in your life?

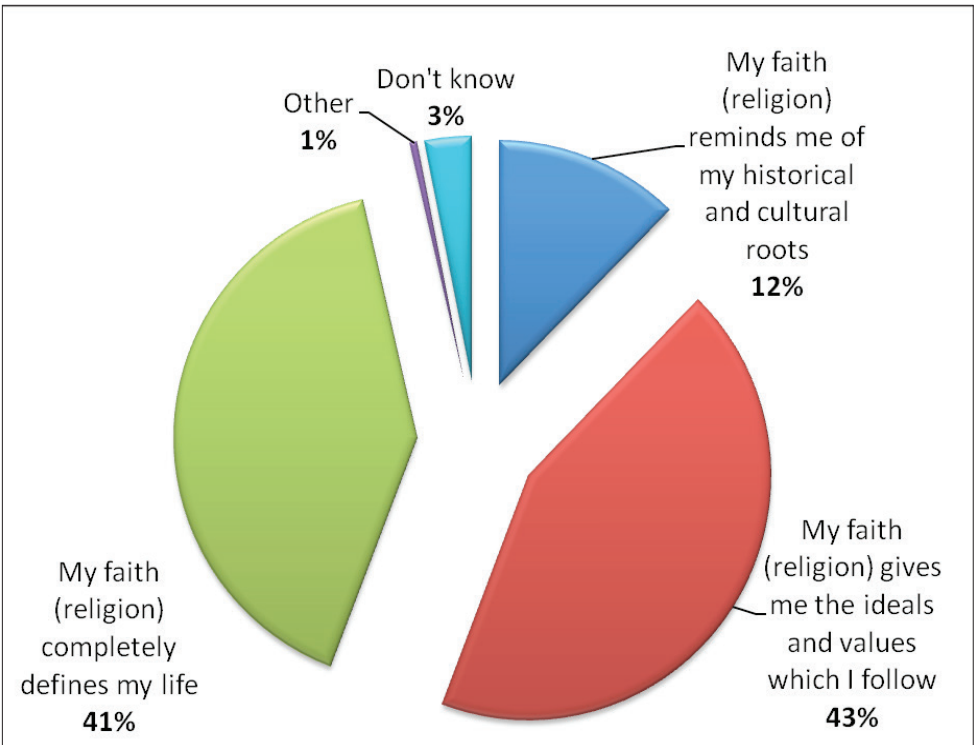

What are you ready to do following your faith (religion)?

To tell others about your faith (religion), to preach

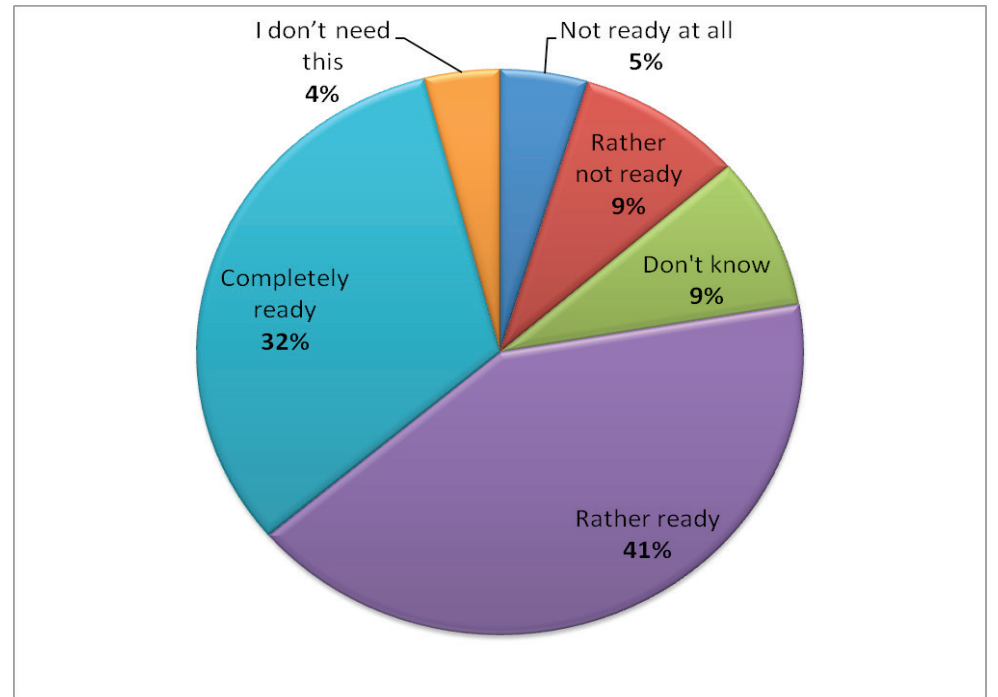


To protect your faith (religion) in arguments if necessary

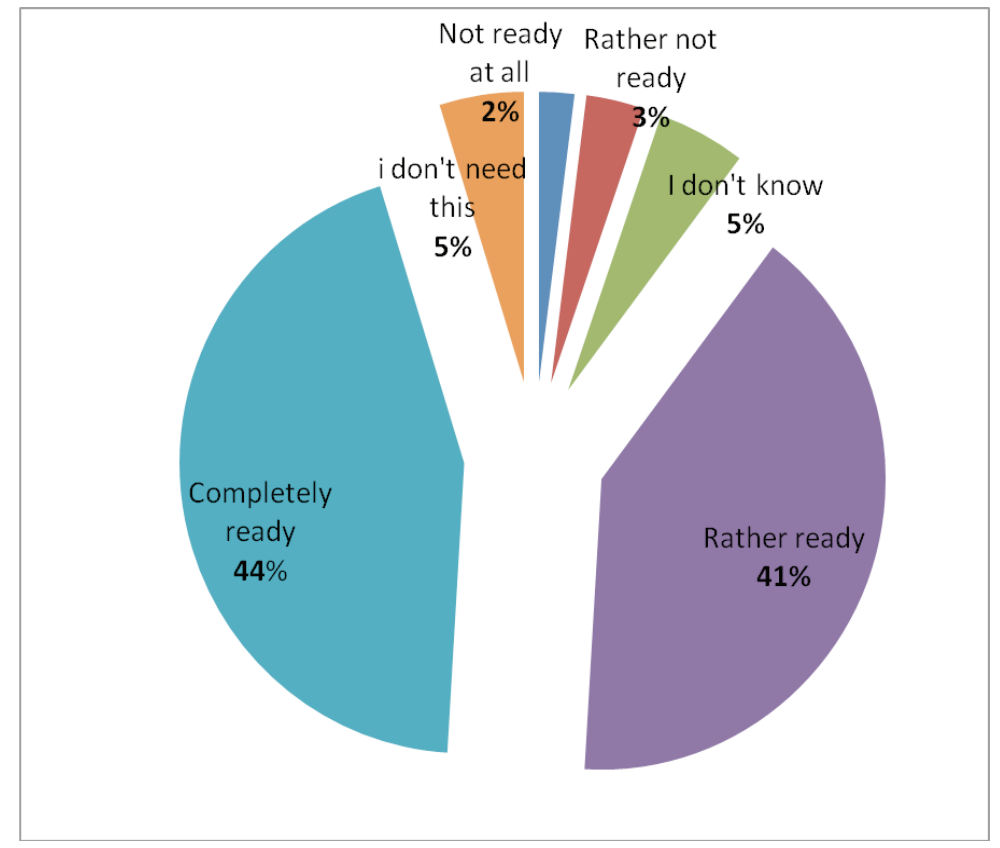

To live in accordance with what you believe in, with your religion's doctrine

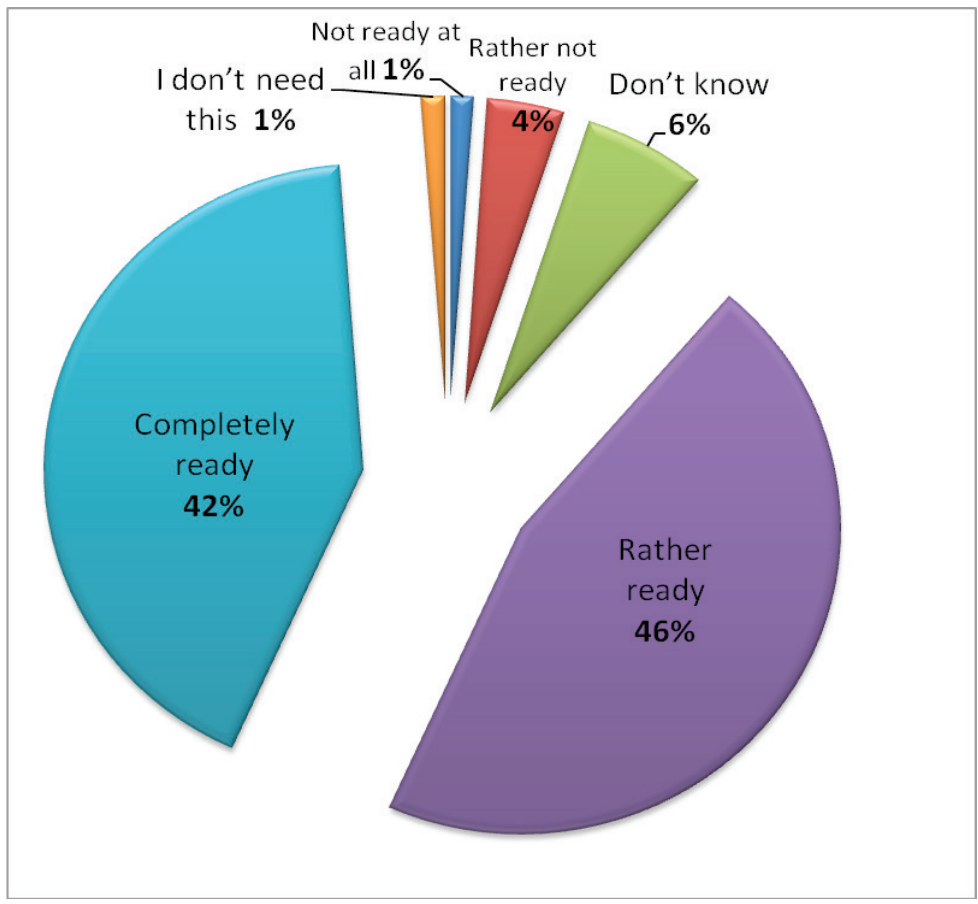


To sacrifice material wealth for your faith (religion)

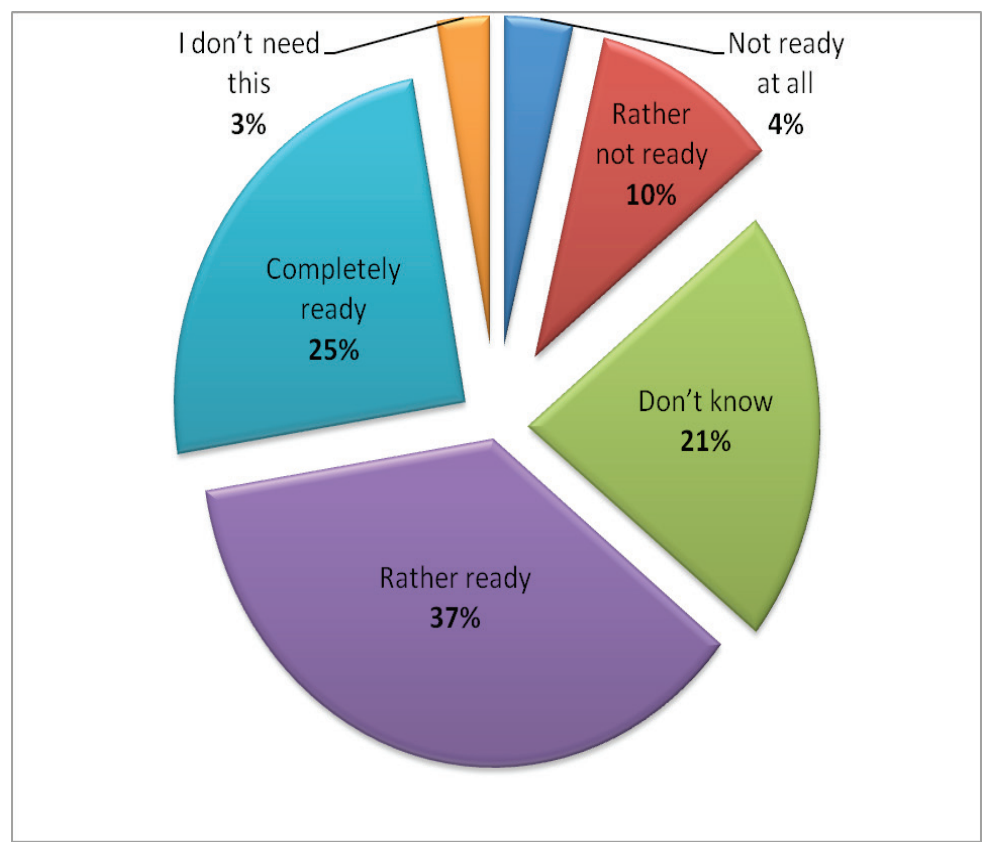

To sacrifice your work, career, social status for your faith (religion)

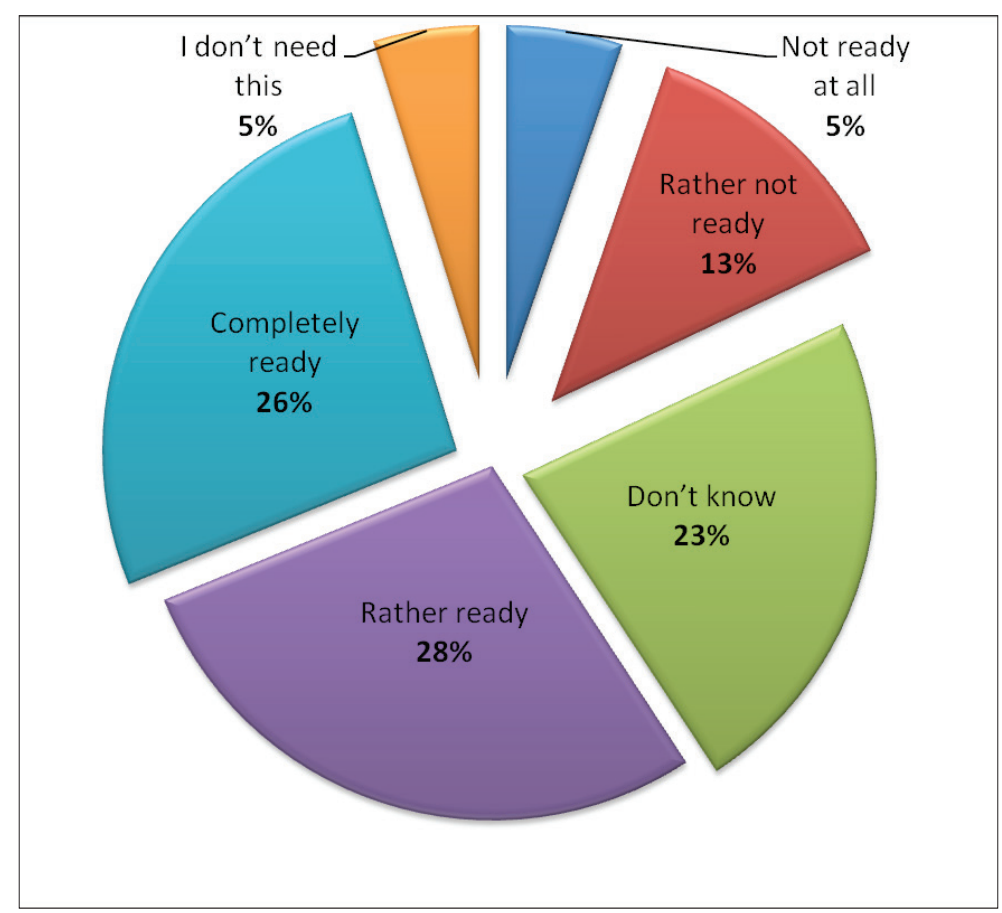


To sacrifice family relationship for your faith (religion)

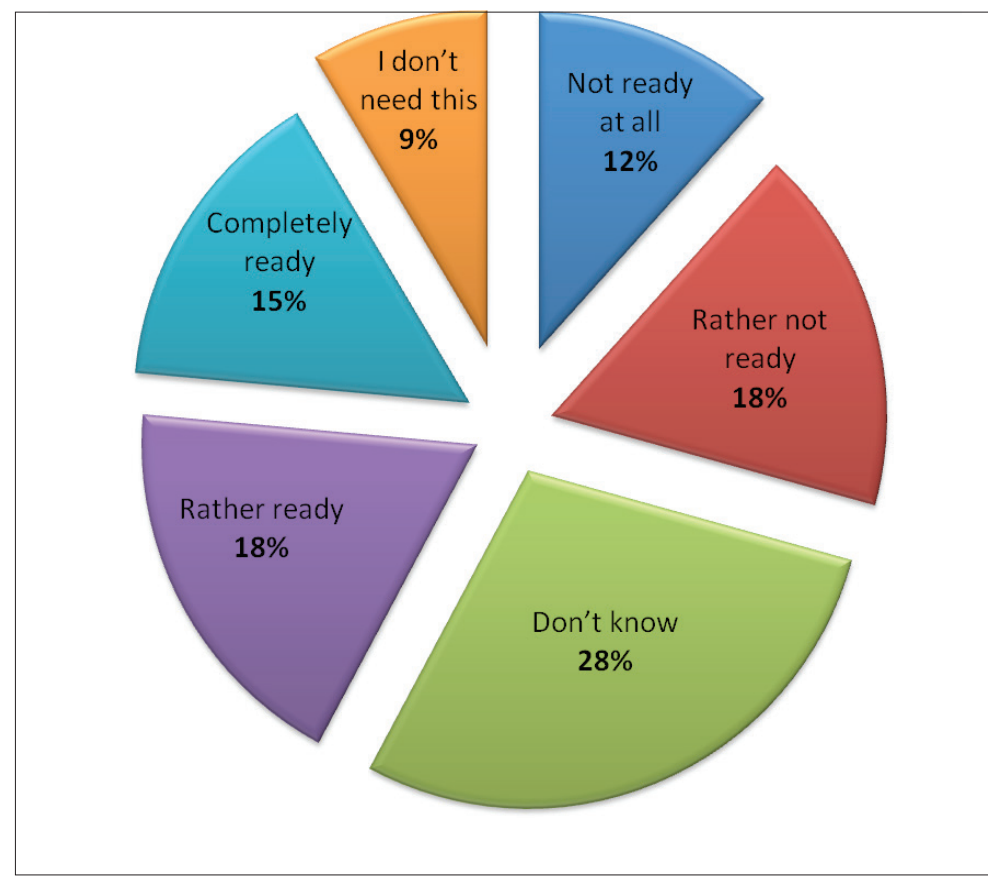

If necessary, give life for your faith (religion)

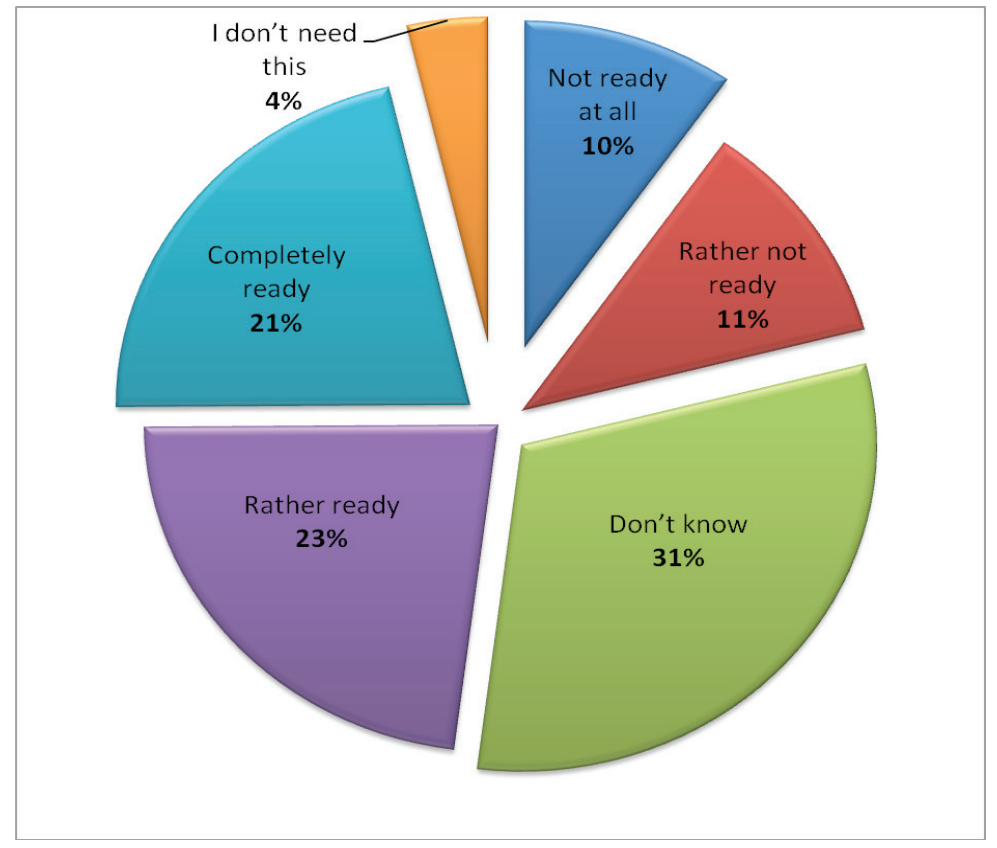


Do you constantly control whether you comply with the demands of your religion: - in your thoughts

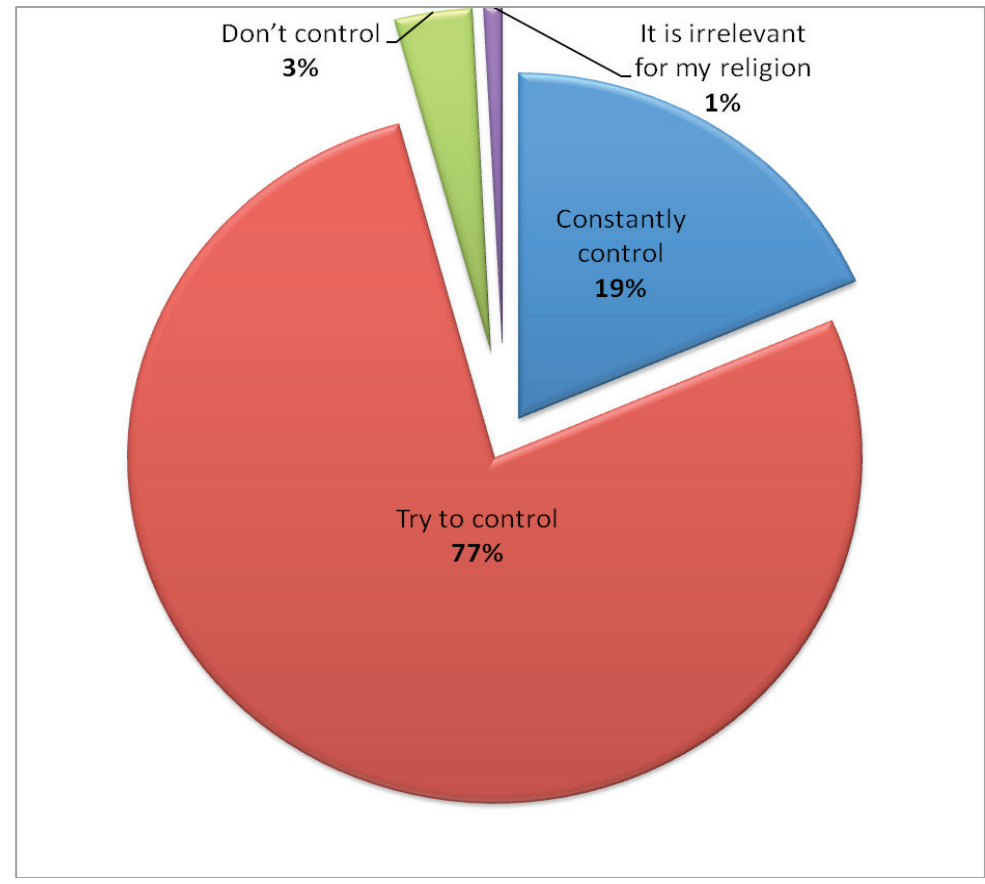

- in your words

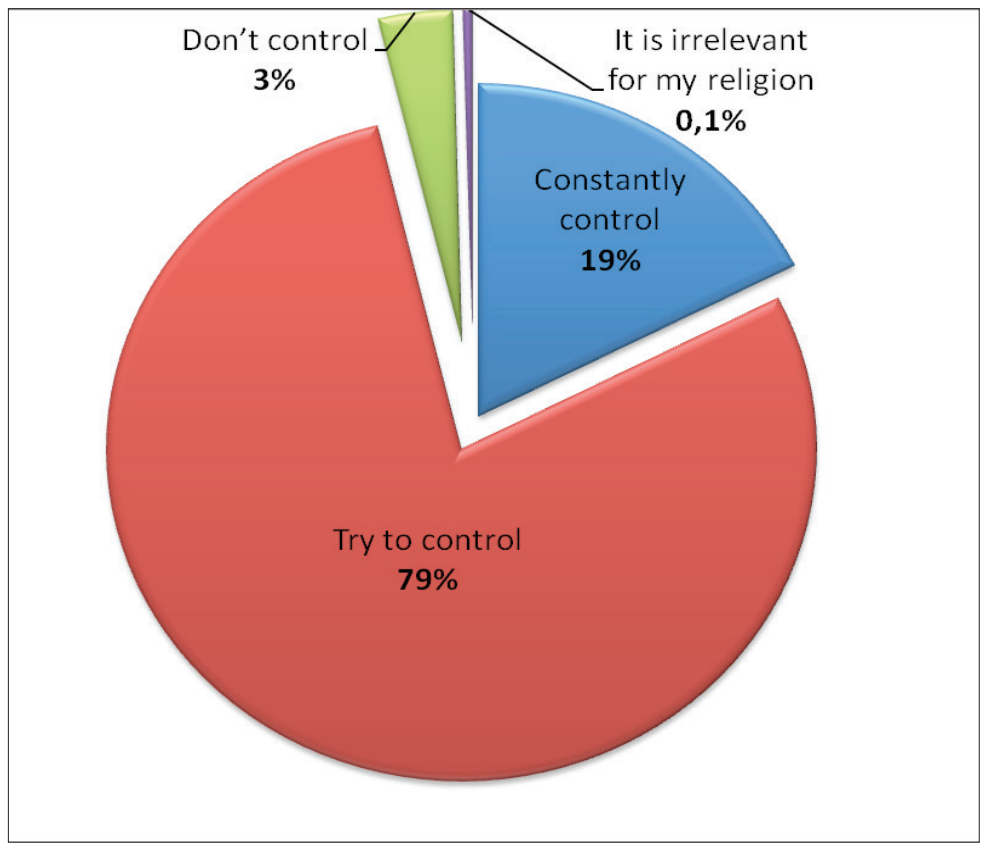


- in your deeds

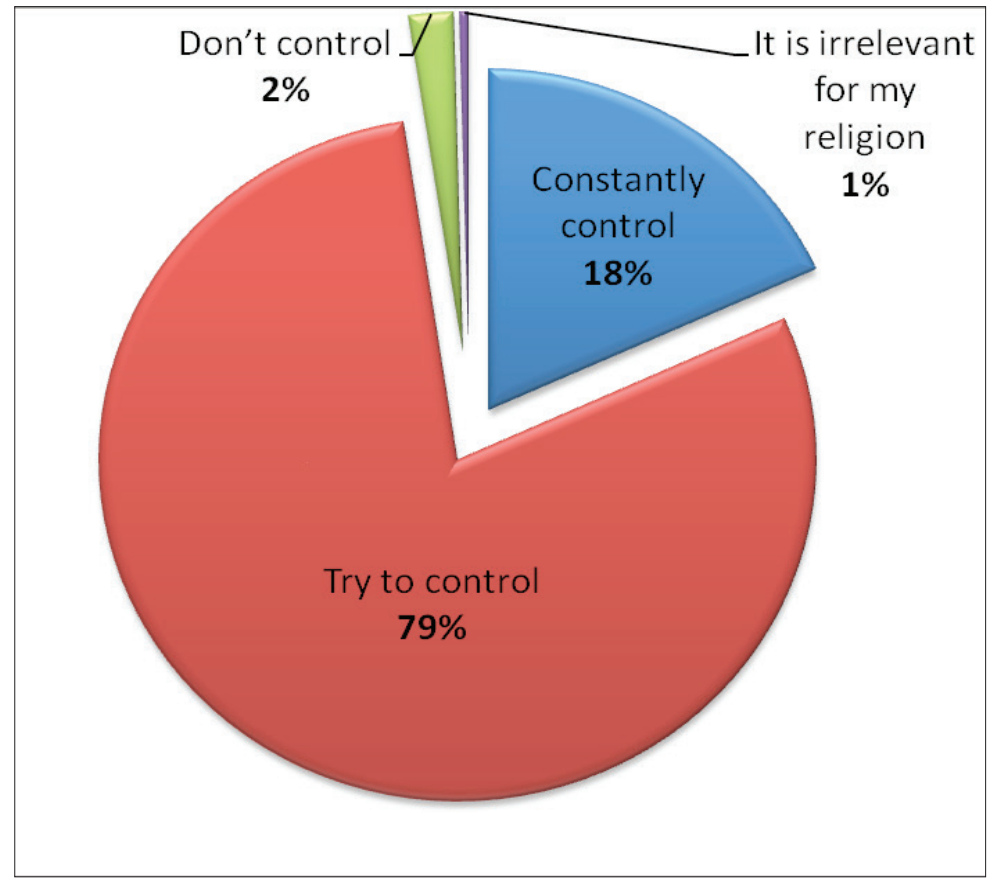

You think that the goals of religious life can be achieved by you:

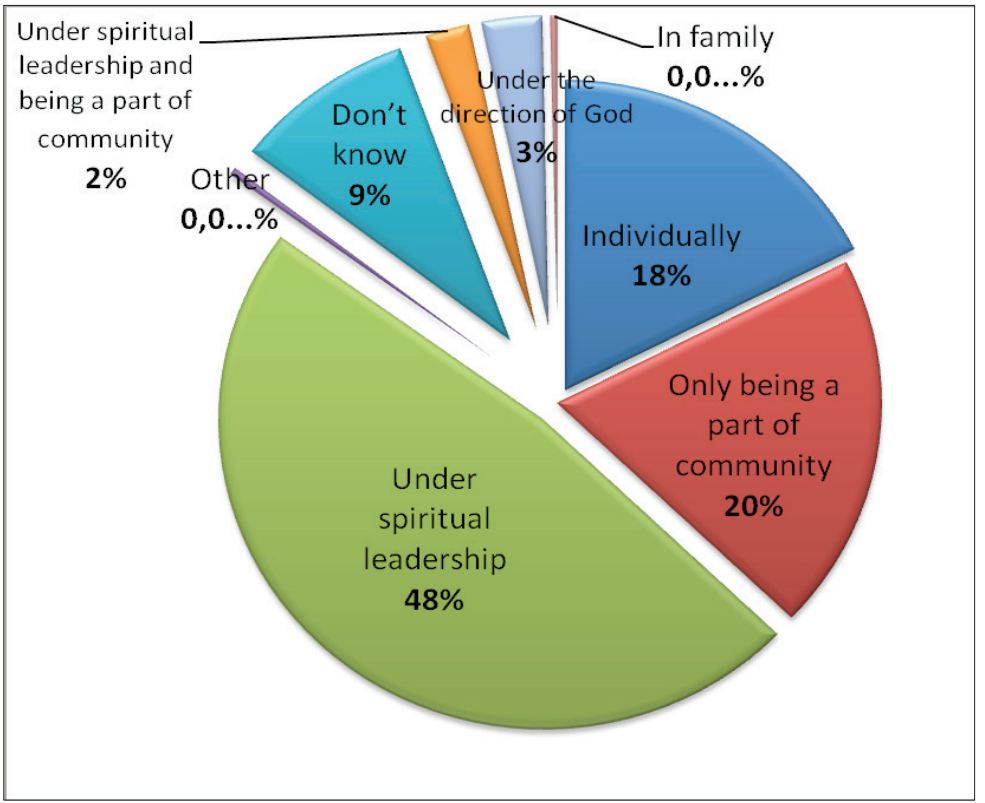


Do you belong to any religious community (group)?

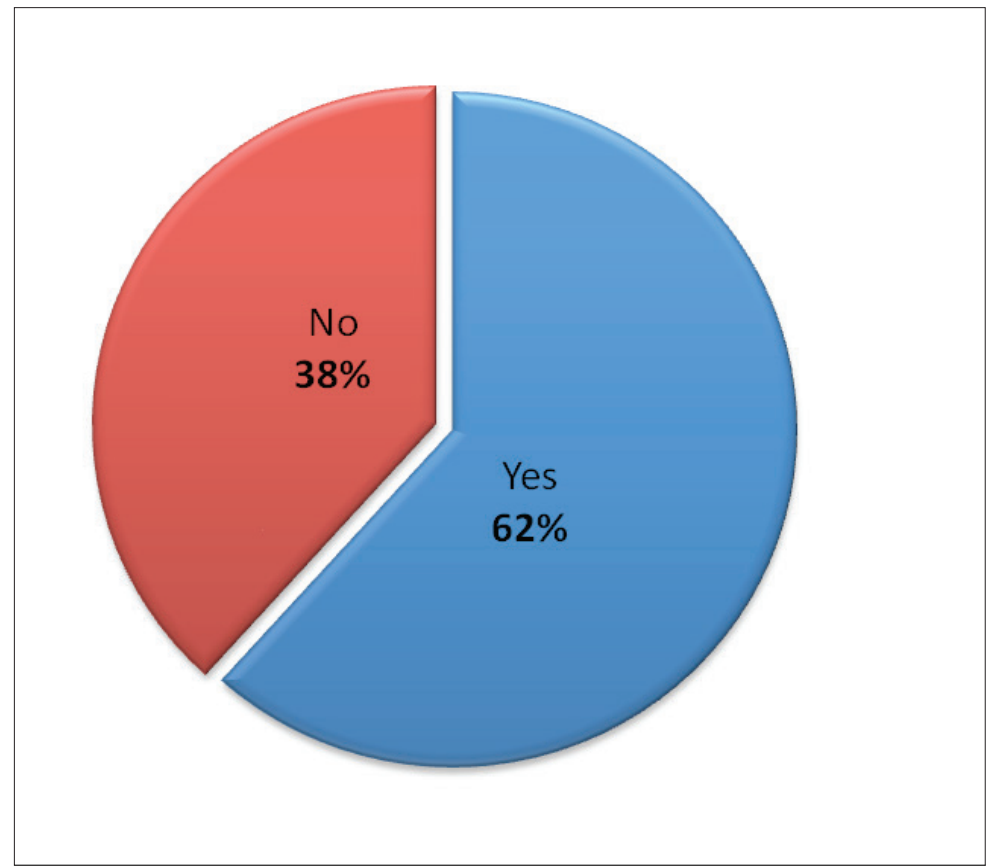

$62 \%$ of those who are part of the community:

What is your position in the religious community (group)?

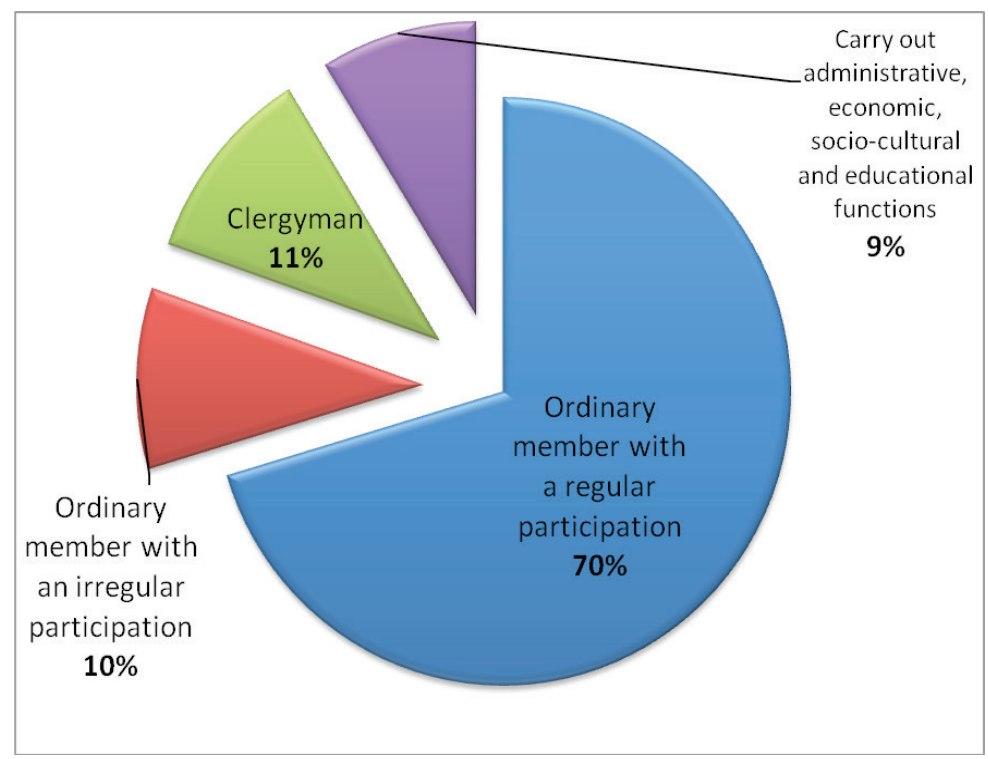


SUMMARY: ORTHODOX RELIGIOSITY IN MODERN BELARUS: AFTER TRADITION'S BREAK (PRELIMINARY DATA). A pre-revolutionary Orthodox tradition in Russia (which included the territory of Belarus as well) originated in the idea of Byzantine Hesychasm about personal transfiguration and the transfigured serving of God. The topic of the transfigured serving (including secular one) was a Russian continuation of this idea. Nevertheless, although the topic of personal transfigured serving was respected in the Russian Orthodoxy, it did not become the fundament of religion: mass Orthodoxy in Russia was authoritative and directive by nature. After a break in tradition during the Soviet period (1917-1991) and during its following rapid revival, mass restoration of religious memory took place. It expectedly took shape of the mass pre-revolutionary variant of Orthodoxy, authoritative and communal. This type of Orthodoxy is executed in Russia in active interaction of the Church and the State; in Belarus in civil collectivism. It is only in recent years that the stabilisation of mass growth of religiosity has led to the growth of individual consciousness in religious stance of the followers of Orthodoxy and other denominations. The represented data illustrate various aspects of religion's significance for its followers.

Doc. Svetlana Karassyova, $\mathrm{PhD}$.

Byelorussian State University

Faculty of Philosophy and Social Science

Philosophy of Culture Department

Kalvaryiskaya 9

220004 Minsk

Belarus

karassyova@mail.ru 